\title{
PENGARUH KARAKTERISTIK PEMERINTAH DAERAH TERHADAP KINERJA KEUANGAN PEMERINTAH DAERAH KABUPATEN DAN KOTA DI JAWA TIMUR
}

\author{
Tatas Ridho Nugroho ${ }^{1}$ \\ Fakultas Ekonomi \\ Universitas Islam Majapahit \\ tatasridho@unim.ac.id
}

\author{
Novi Eko Prasetyo² \\ Fakultas Ilmu Sosial dan Humaniora \\ IKIP Budi Utomo Malang \\ novieko45@gmail.com
}

\begin{abstract}
ABSTRAK
Penelitian ini bertujuan untuk menguji pengaruh karakteristik pemerintah daerah terhadap kinerja keuangan pemerintah daerah. Sampel penelitian ini adalah 30 Kabupaten/Kota di Jawa Timur. Alat analisis yang digunakan dalam penelitian ini adalah regresi berganda. Berdasarkan hasil analisis disimpulkan bahwa secara parsial ukuran pemerintah daerah size berpengaruh negatif terhadap kinerja keuangan pemerintah daerah karena Kebanyakan aset yang dimiliki pemerintah daerah adalah aset yang kurang produktif untuk meningkatkan kinerja keuangan pemerintah daerah. Intergovernmental revenue berpengaruh positif terhadap kinerja keuangan pemerintah daerah karena pemerintah daerah kabupaten/kota mampu menggunakan dana transfer dari pemerintah pusat dengan maksimal, sedangkan belanja daerah berpengaruh negatif terhadap kinerja keuangan pemerintah daerah karena proporsi belanja daerah yang dikeluarkan oleh pemerintah daerah lebih banyak digunakan untuk kebutuhan konsumtif daripada kebutuhan produktif seperti belanja modal.
\end{abstract}

Kata Kunci : Kinerja Keuangan Pemerintah Daerah; Size; Intergovernmental Revenue dan Belanja Daerah.

\section{ABSTRACT}

This study aims to examine the effect of local government characteristics on the financial performance of local governments. The sample of this research is 30 districts / cities in East Java. The analytical tool used in this study is multiple regression. Based on the results of the analysis, it is concluded that partially the size of the local government size has a negative effect on the financial performance of the local government because most of the assets owned by local government are less productive assets to improve the financial performance of local government. Intergovernmental revenues have a positive effect on the financial performance of local governments because the district / city government is able to utilize transfer funds from the central government maximally, while regional expenditures negatively affect the financial performance of local governments because the proportion of local spending issued by the local government is more widely used for consumptive needs rather than productive needs such as capital expenditures.

Keywords: Local Government Financial Performance; Size; Intergovernmental Revenue and Regional Expenditure

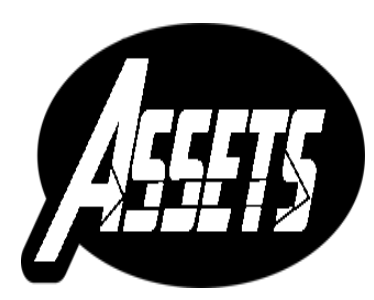

ASSETS

Jurnal Akuntansi dan Pendidikan

Vol. 7 No. 1

Hlmn. 27-34

Madiun, April 2018 p-ISSN: 2302-6251 e-ISSN: 2477-4995

Artikel masuk: 9 November 2017 Tanggal diterima:

27 April 2018 


\section{PENDAHULUAN}

Indonesia adalah negara yang menganut sistem demokrasi yang diamanahkan dalam UUD 1945. Penerapan otonomi daerah di indonesia dimaksutkan untuk memberikan kekuasakan kepada daerah otonom yang memiliki kewajiban mengatur dan mengurus sendiri urusan pemerintahan dan kepentingan masyarakat setempat menurut aspirasi masyarakat untuk meningkatkan produktifitas daerah. Sesuai dengan UU no.32 tahun 2004 tentang pemerintah daerah, bahwa setiap pemerintah daerah diberi kesempatan dalam melaksanakan kewenangan yang menjadi hak daerah. Maju atau tidaknya suatu daerah sangat ditentukan oleh kemampuan dan kemauan pemerintah daerah untuk melaksanakan otonomi daerah dengan baik. Pemerintah daerah dapat mengeksplor keunggulan daerahnya dalam rangka pembangunan sesuai ketentuan perundang-undangan.

Halim (2012: 232), mendefinisikan “Kinerja keuangan daerah merupakan salah satu ukuran yang dapat digunakan untuk melihat kemampuan daerah dalam menjalankan otonomi daerah. Pengukuran kinerja bertujuan untuk mengomunikasikan strategi dengan baik, indikator ketercapaian kinerja keuangan dan non-keuangan, menginformasikan manajer dalam pengambilan keputusan. mengukur tingkat kepuasan individual dan kelompok secara rasional (Mardiasmo, 2009).

Pengukuran kinerja pemerintah daerah (Pemda) harus mencakup pengukuran kinerja keuangan dan non keuangan. Sistem pengukuran kinerja ini akan mengintegrasikan proses peningkatan kinerja melalui tahap mulai perencanaan sampai dengan evaluasi capaiannya. Kinerja bisa digunakan sebagai ukuran keberhasilan aktivitas dari suatu kegiatan selama periode tertentu (Azhar, 2008). Analisis kinerja keuangan pemerintah daerah hakikatnya tidak hanya sebagai bentuk pengendalian, namun juga membantu semua pengguna laporan keuangan pemerintah daerah termasuk masyarakat untuk dapat mengevaluasi kinerja pemerintah daerah.

Peneliti merujuk pada penelitiannya Sesotyaningtyas (2012), berdasarkan rasio efisiensi kinerja bahwa intergovernmental revenue tidak berpengaruh terhadap kinerja keuangan pemerintah daerah. Perbedaan penelitian ini dengan penelitian terdahulu adalah adanya penambahan variabel dengan belanja daerah, karena belanja daerah dapat meningkatkan kualitas dan produktifitas daerah.

Size pemerintah daerah merupakan salah satu karakteristik pemerintah daerah. Ukuran pemerintah daerah menunjukkan seberapa besar organisasi pemerintahan tersebut (Suhardjanto et al., 2010). Ukuran pemerintah daerah menurut Sumarjo (2010) menggunakan total aset pemerintah daerah karena aset menunjukkan sumber daya ekonomi yang dikuasai dan atau dimiliki pemerintah sebagai akibat dari peristiwa masa lalu dan dari mana manfaat ekonomi di masa depan diharapkan dapat diperoleh (Syafitri, 2012). Berdasarkan penelitian Sumarjo (2010) peneliti menggunakan total aset sebagai proksi untuk mengukur pemerintah daerah.

Intergovernmental revenue merupakan bagian dari pendapatan yang berasal dari lingkungan eksternal dan besarnya ketergantungan Pemerintah Daerah dari transfer pemerintah pusat (Sumarjo, 2010). Intergovernmental Revenue biasa dikenal dengan dana perimbangan (Suhardjanto et al., 2010). Proksi dari intergovernmental revenue dalam penelitian ini menggunakan perbandingan antara total dana perimbangan dengan total pendapatan (Sumarjo, 2010). Pengukuran ini dipilih karena intergovernmental revenue merupakan bagian dari pendapatan daerah yang berasal dari lingkungan eksternal (luar kotamadya) dan besarnya ketergantungan pemerintah daerah dari transfer pemerintah pusat (80\% - 98\%) (Suhardjanto et al., 2010). 


\section{intergovernmental revenue $=\frac{\text { Total Dana Perimbangan }}{\text { Total Pendapatan }}$}

Belanja Daerah dikelompokkan menjadi dalam dua jenis yaitu belanja tidak langsung dan belanja langsung. Belanja tidak langsung meliputi belanja pegawai, belanja bunga, belanja subsidi, belanja hibah, belanja bantuan sosial, belanja bagi hasil kepada propinsi/kabupaten dan pemerintah desa, belanja bantuan keuangan kepada propinsi/kabupaten dan pemerintah desa, belanja tidak terduga. Sedangkan belanja langsung meliputi belanja pegawai, belanja barang dan jasa, belanja modal (Badan Pusat Statistik,2010).

Bastian (2010) kinerja keuangan dapat didefinisikan sebagai prestasi yang dicapai oleh organisasi dalam periode tertentu. Salah satu cara yang dapat digunakan untuk mengukur kinerja keuangan pemerintah daerah dengan melihat tingkat efisiensi pemerintah daerah tersebut (Sumarjo, 2010). Sedangkan menurut Sesotyaningtyas (2012), pengukuran kinerja sangat penting untuk menilai akuntabilitas organisasi yaitu dengan pembelanjaan secara efisien dan efektif dalam pelayanan publik. Akuntabilitas dapat terwujud salah satunya dengan melakukan pelaporan kinerja melalui laporan keuangan (Mahmudi, 2010). Rasio efiensi merupakan perbandingan antara besarnya biaya yang dikeluarkan dengan pendapatan yang diterima. Efisiensi pendapatan pemerintah daerah jika rasionya $<1$ atau $<100 \%$.

$$
\text { Efisiensi }=\frac{\text { Realisasi Pengeluaran }}{\text { Realisai Pendapatan }}
$$

\section{METODE PENELITIAN}

Jenis penelitian ini adalah penelitian kuantitatif. Penelitian kuantitatif adalah data yang diukur dalam suatu skala numerik (angka) yang dapat dianalisis dengan menggunakan analisis statistik. Penelitian kuantitatif menurut Sugiyono (2009: 8) dapat diartikan sebagai metode penelitian yang berlandaskan pada filsafat positivisme, digunakan untuk meneliti pada populasi atau sampel tertentu, pengumpulan data menggunakan instrumen penelitian, analisis data bersifat kuantitatif/statistik, dengan tujuan untuk menguji hipotesis yang telah ditetapkan. Variabel bebas dalam penelitian ini adalah ukuran (size) pemerintah daerah (X1), intergovermental revenue (X2), dan belanja daerah (X3). kinerja keuangan pemerintah daerah (Y1) merupakan variabel terikat.

Populasi pada penelitian ini adalah Pemerintah Daerah kabupaten/kota Jawa Timur yang berjumlah 38 daerah. Teknik pengambilan sampel dilakukan secara purposive sampling yaitu pengambilan sampel yang dilakukan berdasarkan kriteria yang dibuat peneliti. Kriteria dalam penelitian ini adalah : 1)Laporan keuangan pemerintah Jawa Timur pada tahun 2013 dari situs resmi www.djpk.kemenkeu.go.id. 2)Daerah yang menyajikan laporan keuangan secara lengkap. Berdasarkan kriteria tersebut, terdapat 30 daerah yang memenuhi kriteria, sehingga jumlah sampel 30 daerah. Jenis data dalam penelitian ini adalah data sekunder. Teknik pengumpulan data dalam penelitian ini melalui pengambilan data laporan keuangan pemerintah daerah kabupaten/kota. Teknik analisis data menggunakan pendekatan asosiatif kausal, sedangkan dalam pelaksanaannya dilakukan melalui program SPSS (statistical Product and Service Solution) versi 16.00 for windows.

\section{HASIL PENELITIAN DAN PEMBAHASAN}

Berdasarkan Lampiran 1, hasil uji t diketahui bahwa Size (x1) memiliki nilai Standardized Coefecient/Beta 0,377 dan nilai sig 0,144. Hasil tersebut menunjukkan 
bahwa nilai sig lebih besar dari 0,05. Sehingga dapat disimpulkan bahwa H0 yang berbunyi "tidak ada pengaruh signifikan size terhadap kinerja keuangan pemerintah daerah" diterima, dan Ha yang berbunyi "Ada pengaruh signifikan size terhadap kinerja keuangan pemerintah daerah" ditolak. Selanjutnya I_Revenue (x2) memiliki nilai Standardized Coefecient/Beta 0,773 dan nilai sig 0,000. Hasil tersebut menunjukkan bahwa nilai sig lebih kecil dari 0,05. Sehingga dapat disimpulkan bahwa H0 yang berbunyi "tidak ada pengaruh signifikan I_Revenue terhadap kinerja keuangan pemerintah daerah" ditolak, dan Ha yang berbunyi "Ada pengaruh signifikan I_Revenue terhadap kinerja keuangan pemerintah daerah" diterima. Belanja daerah $(\mathrm{x} 3)$ memiliki nilai Standardized Coefecient/Beta $-0,086$ dan nilai sig 0,711. Hasil tersebut menunjukkan bahwa nilai sig lebih besar dari 0,05. Sehingga dapat disimpulkan bahwa H0 yang berbunyi "tidak ada pengaruh signifikan belanja daerah terhadap kinerja keuangan pemerintah daerah" diterima, dan Ha yang berbunyi "Ada pengaruh signifikan belanja daerah terhadap kinerja keuangan pemerintah daerah" ditolak.

Berdasarkan Lampiran 2, hasil uji F diketahui bahwa nilai Sig. 0,003 $<0.05$. Maka dapat disimpulkan bahwa H0 yang berbunyi "tidak ada pengaruh signifikan antara Size, I_Revenue dan belanja daerah terhadap kinerja keuangan pemerintah daerah" ditolak, dan Ha yang berbunyi "Ada pengaruh signifikan antara Size, I_Revenue dan belanja daerah terhadap kinerja keuangan pemerintah daerah" diterima.

\section{Pengaruh size terhadap kinerja keuangan pemerintah daerah}

Tujuan utama dari program kerja pemerintah daerah adalah memberikan pelayanan yang terbaik untuk masyarakat. Untuk memberikan pelayanan yang baik, harus didukung oleh aset yang baik pula. Oleh karena itu, diperlukan sumber daya dan fasilitas yang memadai untuk memberikan pelayanan kepada masyarakat. Semakin besar ukuran daerah yang ditandai dengan besarnya jumlah aset pemerintah daerah, maka diharapkan akan semakin tinggi kinerja Pemerintah daerah tersebut (Mustikarini dan Fitriasasi, 2012: 6).

Hasil analisis regresi liniear berganda, variabel size menunjukkan bahwa size memiliki nilai Standardized Coefecient/Beta adalah 0,377 dan nilai sig 0,144. Hasil tersebut menunjukkan bahwa signifikansi lebih besar dari 0,05. Hasil tersebut dapat disimpulkan bahwa variabel size tidak berpengaruh secara signifikan terhadap kinerja keuangan pemerintah daerah.

Temuan ini sejalan dengan penelitian Marfiana dan Kurniasih (2013) yang menyatakan bahwa size daerah tidak berpengaruh signifikan terhadap kinerja keuangan pemerintah daerah. Hal ini mengindikasikan bahwa peran total aset dalam meningkatkan kinerja keuangan pemerintah daerah di Provinsi Jawa Timur belum dapat berfungsi sebagaimana mestinya. Kebanyakan aset yang dimiliki pemerintah daerah adalah aset yang kurang produktif untuk meningkatkan kinerja keuangan pemerintah daerah. Besarnya jumlah aset daerah akan menyulitkan peran pemerintah untuk memonitor masing-masing aset tersebut secara langsung. Hal ini didukung oleh hasil penelitian Marfiana dan Kurniasih (2013) bahwa Pemerintah daerah dengan aset dan kekayaan yang besar pasti memiliki tekanan yang lebih besar pula dari masyarakat untuk lebih baik dalam mengelola dan menggunakan segala sumber daya yang dimilikinya itu guna perbaikan kinerja.

\section{Pengaruh intergovermental revenue terhadap kinerja keuangan pemerintah daerah}

Dana perimbangan digunakan untuk membiayai penyelenggaraan pemerintahan sehingga dapat terlaksana pelayanan kepada masyarakat. Pemerintah akan memantau pelaksanaan dari dana perimbangan sehingga hal ini memotivasi Pemda untuk 
berkinerja lebih baik. Semakin tinggi ketergantungan Pemda pada pemerintah pusat maka diharapkan semakin baik pelayanan Pemda kepada masyarakatnya sehingga kinerja Pemda juga semakin meningkat.

Hasil analisis regresi liniear berganda, variabel intergovernmental revenue menunjukkan bahwa intergovernmental revenue memiliki memiliki nilai Standardized Coefecient/Beta adalah 0,773 dan nilai sig 0,000. Hasil tersebut menunjukkan bahwa signifikansi lebih kecil dari 0,05. Kesimpulannya bahwa variabel intergovernmental revenue berpengaruh secara signifikan terhadap kinerja keuangan pemerintah daerah.

Hal ini dikarenakan pemerintah daerah kabupaten/kota mampu menggunakan dana transfer dari pemerintah pusat dengan maksimal. Dana perimbangan yang meliputi Dana Bagi Hasil Pajak dan Bukan Pajak serta DAU dan DAK merupakan dana transfer dari pemerintah pusat kepada Pemda dengan tujuan untuk membiayai kelebihan belanja daerah. Jika belanja daerah lebih besar daripada pendapatan daerah maka terjadi defisit. Dibutuhkan dana perimbangan dari pemerintah pusat untuk menutupi kekurangan belanja daerah. Semakin besar dana perimbangan yang diterima akan semakin besar anggaran yang dapat dikelola pemerintah daerah untuk memenuhi kebutuhannya.

\section{Pengaruh belanja daerah terhadap kinerja keuangan pemerintah daerah}

Undang-Undang Republik Indonesia Nomor 32 Tahun 2004 Pasal 167 ayat 1 menyatakan bahwa belanja daerah digunakan untuk melindungi dan meningkatkan kualitas kehidupan masyarakat yang diwujudkan dalam bentuk peningkatan pelayanan urusan wajib dan pelayanan lain di bidang pendidikan, kesehatan, penyediaan fasilitas sosial, fasilitas umum, dan pengembangan sistem jaminan sosial. Oleh karena itu, semakin tinggi belanja pemerintah daerah seharusnya mencerminkan semakin tingginya tingkat pelayanan yang diberikan kepada masyarakat. Selanjutnya, semakin tinggi tingkat pelayanan yang diberikan, maka semakin tinggi skor kinerja keuangan pemerintah daerah tersebut.

Hasil analisis regresi liniear berganda, variabel belanja daerah menunjukkan bahwa belanja daerah memiliki nilai Standardized Coefecient/Beta adalah -0,086 dan nilai sig 0,711. Hasil tersebut menunjukkan bahwa signifikansi lebih besar dari 0,05. Kesimpulannya bahwa variabel belanja daerah tidak berpengaruh secara signifikan terhadap Kinerja keuangan pemerintah daerah.

Peningkatan Belanja pemerintah daerah yang tinggi belum tentu meningkatkan pertumbuhan ekonomi. Belanja pemerintah daerah dirasa masih sangat kurang dalam meningkatkan pelayanan yang diberikan kepada masyarakat. Oleh karenanya perlu adanya pengalokasian dana yang lebih tepat sasaran untuk kesejahteraan masyarakat. Hal ini sejalan dengan Kurnia dalam Arowana (2017) yang menyatakan bahwa belanja daerah justru menurunkan pertumbuhan ekonomi. Hal ini disebabkan proporsi belanja daerah yang dikeluarkan oleh pemerintah daerah lebih digunakan untuk membiayai pengeluaran seperti belanja pegawai daripada digunakan untuk membiayai pengeluaran-pengeluaran yang produktif seperti belanja modal.

\section{Pengaruh Size, Intergovernmental revenue, dan Belanja daerah terhadap kinerja keuangan pemerintah daerah.}

Kinerja keuangan pemerintah daerah kota dan kabupaten di Jawa Timur di pengaruhi oleh beberapa faktor antara lain Size, Intergovernmental revenue, dan Belanja daerah. Terukurnya kinerja keuangan pemerintah daerah akan berdampak pada kinerja pemerintah daerah yang semakin baik. Hasil uji regresi ganda antara Size, Intergovernmental revenue, dan Belanja daerah secara simultan terhadap kinerja 
keuangan pemerintah daerah diketahui nilai sig F $0.003<0.05$. Sehingga dapat disimpulkan bahwa variabel Size, Intergovernmental revenue, dan Belanja daerah secara simultan berpengaruh terhadap kinerja keuangan pemerintah daerah.

Berdasarkan hasil analisis dapat diketahui bahwa kontribusi tertinggi dalam penelitian ini adalah Intergovernmental revenue. Hal ini dikarenakan Intergovernmental revenue / dana transfer dari pemerintah pusat sudah bisa dimaksimal dan dialokasikan oleh pemerintah daerah untuk membiayai kelebihan belanja daerah. Semakin besar dana perimbangan yang diterima pemerintah daerah maka dapat mempermudah pemerintah daerah dalam memenuhi kebutuhannya. Faktor lain seperti size dan belanja daerah kurang memiliki kontribusi disebabkan size total aset belum dapat berfungsi semestinya dalam meningkatkan kinerja keuangan pemerintah daerah di Provinsi Jawa Timur. Sedangkan belanja pemerintah daerah dirasa masih sangat kurang dalam meningkatkan pelayanan yang diberikan kepada masyarakat.

\section{SIMPULAN}

Ukuran (size) pemerintah daerah tidak berpengaruh terhadap kinerja keuangan pemerintah daerah. Hal ini mengindikasikan bahwa peran total aset dalam meningkatkan kinerja keuangan pemerintah daerah di Jawa Timur belum dapat berfungsi sebagaimana mestinya. Dari total aset yang dimiliki pemerintah daerah, asset tetap lebih dominan daripada asset lancar. Asset tetap yang dimiliki daerah kurang produktif untuk meningkatkan daya saing daerah.

Intergovernmental revenue berpengaruh terhadap kinerja keuangan pemerintah daerah. Hal ini dikarenakan pemerintah daerah kabupaten/kota mampu menggunakan dana transfer dari pemerintah pusat dengan maksimal. Dana perimbangan yang meliputi Dana Bagi Hasil Pajak dan Bukan Pajak serta DAU dan DAK merupakan dana transfer dari pemerintah pusat kepada Pemda dengan tujuan untuk membiayai kelebihan belanja daerah. Semakin besar dana perimbangan yang diterima akan semakin besar anggaran yang dapat di kelola pemerintah daerah untuk memenuhi kebutuhannya.

Belanja daerah tidak berpengaruh secara signifikan terhadap kinerja keuangan pemerintah daerah. Hal ini disebabkan proporsi belanja daerah yang dikeluarkan oleh pemerintah daerah lebih digunakan untuk membiayai pengeluaran seperti belanja pegawai daripada digunakan untuk membiayai pengeluaran-pengeluaran yang produktif seperti belanja modal. Jika belanja modal sedikit maka pendapatan pemerintah daerah tidak maksimal.

Keterbatasan dalam penelitian ini adalah tidak semua daerah baik kota dan kabupaten di Jawa Timur diteliti, hal ini karena terdapat beberapa laporan keuangan daerah yang tidak dapat diakses.

\section{DAFTAR PUSTAKA}

Anjar, A. (2017). Sudahkah jatim mandiri dalam Otonomi?. Diakses 10 Agustus 2017. https://koranfakta.net/dinamika/tokoh/10174-otonomi-daerah-di-jawa-timurperlu-dikaji-ulang/. Diakses pada 20 Juli 2017, dari http:// kominfo.jatimprov.go.id/read/umum/39351.

Azhar, M. K. S. (2008). Analisa Kinerja Keuangan Pemerintah Daerah Kabupaten/Kota Sebelum dan Setelah Otonomi Daerah. Tesis tidak diterbitkan. Sumatera Utara: Pascasarjana. Universitas Sumatera Utara. http:// siastie.harapan.ac.id/jurnal/index.php/JKB/article/view/45.

Badan Pusat Statistik Jakarta Pusat. (2010), Statistik Indonesia Tahun 2010. Jakarta Pusat: Badan Pusat Statistik. 
Bastian, I. (2010). Akuntansi sektor publik di Indonesia. Yogyakarta: Penerbit BPFE.

Direktorat Jendral Perimbangan Keuangan. (2016). Data Keuangan Daerah. Diakses pada 15 Oktober 2016, dari http:/ / www.djpk.kemenkeu.go.id/ data-series/datakeuangan- daerah/setelah-ta-2006

Halim, A. (2012). Akuntansi sektor publik : akuntansi keuangan daerah. Jakarta: Penerbit Salemba Empat. https://journal.unnes.ac.id/sju/index.php/aaj/article/view/711

Mahmudi. (2010). Manajemen Keuangan Daerah. Jakarta: Penerbit Erlangga.

Mardiasmo. (2009). Akuntansi sektor publik. Yogyakarta: Penerbit Andi Offset.

Marfiana, N dan Kurniasih, L. (2013). Pengaruh karakteristik pemerintah daerah dan hasil pemeriksaan audit BPK terhadap kinerja keuangan pemerintah daerah kabupaten/kota. Jurnal. Sustainable Competitive Advantage (SCA), 3 (1).

Mustikarini, W. A. dan Fitriasari, D. (2012). Pengaruh karakteristik pemerintah daerah dan temuan audit BPK terhadap kinerja pemerintah daerah kabupaen/kota di Indonesia tahun anggaran 2007. In Simposium Nasional Akuntansi XV: Banjarmasin.

Sesotyaningtyas, M. (2012). Pengaruh Leverage, Ukuran Legislatif, Intergovernmental Revenue Dan Pendapatan Pajak Daerah Terhadap Kinerja Keuangan Pemerintah Daerah. Accounting Analysis Journal, 1(1).

Sugiyono. (2009). Metode penelitian kuantitatif, kualitatif dan R\&D. Cetakan Kedelapan. Bandung: Penerbit ALFABETA

Suhardjanto, D., Hartoko, S., Retnoningsih, H., Rusmin, M., Putriesti dan Brown, A. (2010). Influence of Parliament Characteristics toward Mandatory Accounting Disclosure Compliance in Indonesia.

Sumarjo, H. (2010). Pengaruh karakteristik pemerintah daerah terhadap kinerja keuangan pemerintah daerah. Disertasi tidak diterbitkan. Surakarta: Pascasarjana UNS. http:/ / eprints.uns.ac.id/6/1/169921211201009511.pdf

Syafitri, F. (2012). Analisis karakteristik pemerintah daerah terhadap tingkat pengungkapan laporan keuangan. Skripsi tidak diterbitkan. Depok: FE Universitas Indonesia.

Undang-undang Nomor 32 Tahun 2004 tentang Pemerintah Daerah, Departemen Dalam Negeri RI, Jakarta. Diakses pada 18 Agustus 2016, dari www.bapenas.go.id.

\section{LAMPIRAN}

Lampiran 1. Hasil Uji t (Parsial)

\begin{tabular}{|c|c|c|c|c|c|c|}
\hline \multicolumn{7}{|c|}{ Coefficients } \\
\hline \multirow{2}{*}{\multicolumn{2}{|c|}{ Model }} & \multicolumn{2}{|c|}{$\begin{array}{l}\text { Unstandardized } \\
\text { Coefficients }\end{array}$} & \multirow{2}{*}{$\begin{array}{l}\text { Standardized } \\
\text { Coefficients } \\
\text { Beta }\end{array}$} & \multirow[t]{2}{*}{$t$} & \multirow[t]{2}{*}{ Sig } \\
\hline & & B & Std. Error & & & \\
\hline \multirow[t]{4}{*}{1} & (Constant) & ,539 & 136 & & 3,959 & ,001 \\
\hline & Size & $1,538 \mathrm{E}-8$ & ,000 & 377 & 1,506 & 144 \\
\hline & I_Revenue & 677 & 169 & ,773 & 4,001 & ,000 \\
\hline & Belanja_Daerah & $-1,232 \mathrm{E}-8$ &, 000 &,- 086 &,- 375 & ,711 \\
\hline
\end{tabular}

a. Dependent Variable: Efesiensi 
NUGROHO, T. R. \& PRASETYO, N. E. PENGARUH KARAKTERISTIK PEMERINTAH ....

\section{ASSETS}

Lampiran 2. Hasil Uji F (Simultan)

\begin{tabular}{|c|c|c|c|c|c|c|}
\hline \multicolumn{7}{|c|}{ ANOVA $^{b}$} \\
\hline \multicolumn{2}{|c|}{ Model } & Sum & & Mean Square & $\mathrm{F}$ & Sig. \\
\hline \multirow[t]{3}{*}{1} & Regression & ,053 & 3 & ,018 & 5,950 &, $003^{a}$ \\
\hline & Residual & ,077 & 26 & ,003 & & \\
\hline & Total & 130 & 29 & & & \\
\hline
\end{tabular}

a. Predictors: (Constant), Belanja_Daerah, I_Revenue, Size

b. Dependent Variable: Efesiensi 